\title{
Concurrent Treatment of HIV, Disseminated Mycobacterium Avium Complex and HCV- Infection
}

\author{
Vera Zimina ${ }^{1}$, Svetlana Degtyareva ${ }^{1}$, Elena Beloborodova ${ }^{1}$, Julia Klimova ${ }^{1}$, Alexey Kravchenko ${ }^{2}$ \\ ${ }^{1}$ Department of Infectious Diseases, RUDN University, Moscow, Russia \\ ${ }^{2}$ Research Department of AIDS Epidemiology and Prevention, Central Research Institute of Epidemiology, Russian Federal Service for Supervision of \\ Consumer Rights Protection and Human Welfare, Moscow, Russia
}

Corresponding author: Svetlana Degtyareva, Department of Infectious Diseases, RUDN University, 6 Miklukho-Maklaya St., Moscow 117198, Russian Federation; E-mail: degtyareva_syu@pfur.ru; Tel.: 8-(495)-365-25-33

Received: 2 July 2020 Accepted: 14 July $2020 \diamond$ Published: 31 Aug 2021

Citation: Zimina V, Degtyareva S, Beloborodova E, Klimova J, Kravchenko A. Concurrent treatment of HIV, disseminated Mycobacterium avium complex and HCV-infection. Folia Med (Plovdiv) 2021;63(4):586-90. doi: 10.3897/folmed.63.e56124.

\begin{abstract}
Patients with HIV-infection diagnosed at late stages usually have significant immunosuppression and demand simultaneous antiretroviral therapy and treatment of opportunistic infections. The presence of $\mathrm{HCV}$ coinfection makes treatment even more challenging because of possible adverse effects and drug-drug interactions. HCV cure in such clinical situations not only prevents fibrosis progression, but can also enhance virologic and/or immunologic response to antiretrovirals and thus effective treatment of opportunistic infections. Thorough consideration of all existing diseases and drug interactions of the combined therapy makes simultaneous treatment of HIV, chronic hepatitis $\mathrm{C}$, and opportunistic infections not only possible but the best way to improve outcomes in a complex clinical situation.
\end{abstract}

\section{Keywords}

co-infection, drug interactions, hepatitis C, immunosuppression, non-tuberculous mycobacteria

\section{INTRODUCTION}

Both the chronic hepatitis $\mathrm{C}$ virus (HCV) and the human immunodeficiency virus (HIV) are significant public health challenges. Because of the shared modes of transmission, people at risk for HIV infection are also at risk for $\mathrm{HCV}$ infection. According to WHO, there were 71 million people living with chronic HCV infection and 37.9 million people living with HIV in 2018. The global estimate of burden of HIV-HCV co-infection was 2.75 million. Modern antiviral medicines can cure more than $95 \%$ of persons with hepatitis $\mathrm{C}$ infection. WHO's updated 2018 guidelines recommend therapy with pan-genotypic direct-acting antivirals (DAAs) for all persons with chronic HCV infection over the age of $12 .{ }^{1}$ Access to HCV treatment is improving globally but remains limited. DAAs remain expensive in many high- and upper-middle-income countries, including the Russian Federation where the generic versions of these medicines are not licensed.

The rate of HIV infection is high in the Russian Federation. The disease is often detected in late stages when patients already suffer from one or more opportunistic infections. 106560 new cases were detected in 2017 and this rate increases yearly according to the Federal Scientific and Methodological Centre for AIDS Prevention and Control. ${ }^{2}$ Among patients under outpatient clinics observation in 2017, 22.3\% had late stages of HIV-infection. ${ }^{3}$ Parenteral drug use is still a common way of HIV transmission (18.9\% of all newly diagnosed in 2017 according to official data). Therefore, coinfection with chronic hepatitis $\mathrm{C}$ is not rare and this poses additional challenges to treating such patients.

Copyright by authors. This is an open access article distributed under the terms of the Creative Commons Attribution License (CC-BY 4.0), 


\section{CASE REPORT}

A 37-year-old man was diagnosed with HCV infection in 1998 (positive HCV-antibody test), but did not receive any antiviral treatment. In 2015, he was recommended treatment with DAAs.

Routine screening prior to the treatment revealed METAVIR score F3 liver fibrosis (on elastography), hepatosplenomegaly and signs of portal hypertension (on sonography). He was classified as Child Pugh Class A. No signs of liver decompensation were detected. HCV genotype was defined as $3 a$. HBsAg was negative. He had never been tested for $H I V$ previously and the screening revealed HIV-infection. He had an advanced immunosuppression with 0 cells/mcl CD4 cell count and a viral load (VL) of 400000 copies $/ \mathrm{ml}$. Though the patient had at least 4 factors associated with accelerated fibrosis progression (F3 liver fibrosis, 3 a genotype of HCV, male sex, and HIV-coinfection), antiviral HCV treatment was delayed until the stabilization in the HIV status. In November 2015, the patient began antiretroviral treatment (ART) with lopinavir/ritonavir plus tenofovir plus lamivudine and co-trimaxozole prophylaxis in accordance with the national guidelines. ${ }^{4}$ CT scan of the chest showed moderate axillar lymphadenophathy. We also initiated treatment of latent tuberculosis infection (LTBI) (isoniazid 0.3 plus vitamin B6). We did not prescribe primary prophylaxis of MAC infection as the risk was relatively low and because of possible drug interactions and accelerated fibrosis. In December 2015, the CD4 count was 29 cells/mcl, RNA HIV was 687 copies $/ \mathrm{ml}$.

By May 2016, when LTBI treatment was almost over, the patient's condition worsened. He developed fever, chills, dry cough, increasing shortness of breath. He had bouts of diarrhea every morning and once experienced bloody sputum. He was admitted to the hospital for infectious diseases. Chest CT scan on June 1, 2016 showed a progressive disease: enlargement of left bronchopulmonary chest lymph nodes with compression of bronchi of the left upper lobe as well as single foci in the upper lobe of the left lung (Figs 1A, 1B). The abdominal MRI on June 9 detected enlarged lymph nodes in ligamentum hepato-mesenteric and mesenteric lymph nodes $(8.5 \times 9 \mathrm{~mm}, 18 \times 15 \mathrm{~mm})$, para-aortic lymph nodes were also involved $(10 \times 11 \mathrm{~mm}, 15 \times 18 \mathrm{~mm})$ (Fig. 2). Fibrobronchoscopy on June 22 revealed signs of tuberculosis in the left upper lobar bronchus and left B6 bronchus, bronchonodular fistulas.

Sputum and bronchoalveolar lavage revealed acid-fast bacilli 3 per 100 fields and 40 per 100 fields, fecal tests at the same time detected acid-fast bacilli 2 per 100 fields. PCR of the sputum performed on June 20 detected no DNA of Mycobacterium tuberculosis complex. Thus disseminated Mycobacterium avium complex (MAC) infection was suspected. Blood culture for mycobacteria detection was not available. In July 2016, we initiated treatment with clarythromy 1.0 , rifabutin 0.15 , ethambutol 1.2 , and moxifloxacin 0.4 according to ATS guidelines for treatment of nontuberculous mycobacterial diseases ${ }^{5}$ and national guidelines for treatment of HIV infections ${ }^{4}$. In August 2016, culture from sputum was identified with Genotype Mycobacterium CM (Hain Lifescience, Germany) as M. avium. Therefore, the diagnosis was confirmed. At the same time, our patient developed esophageal candidiasis which was successfully treated with fluconazole (there was no evidence of varices on endoscopy).

The patient was under the observation of an HIV specialist after he was discharged. He continued treatment of MAC-

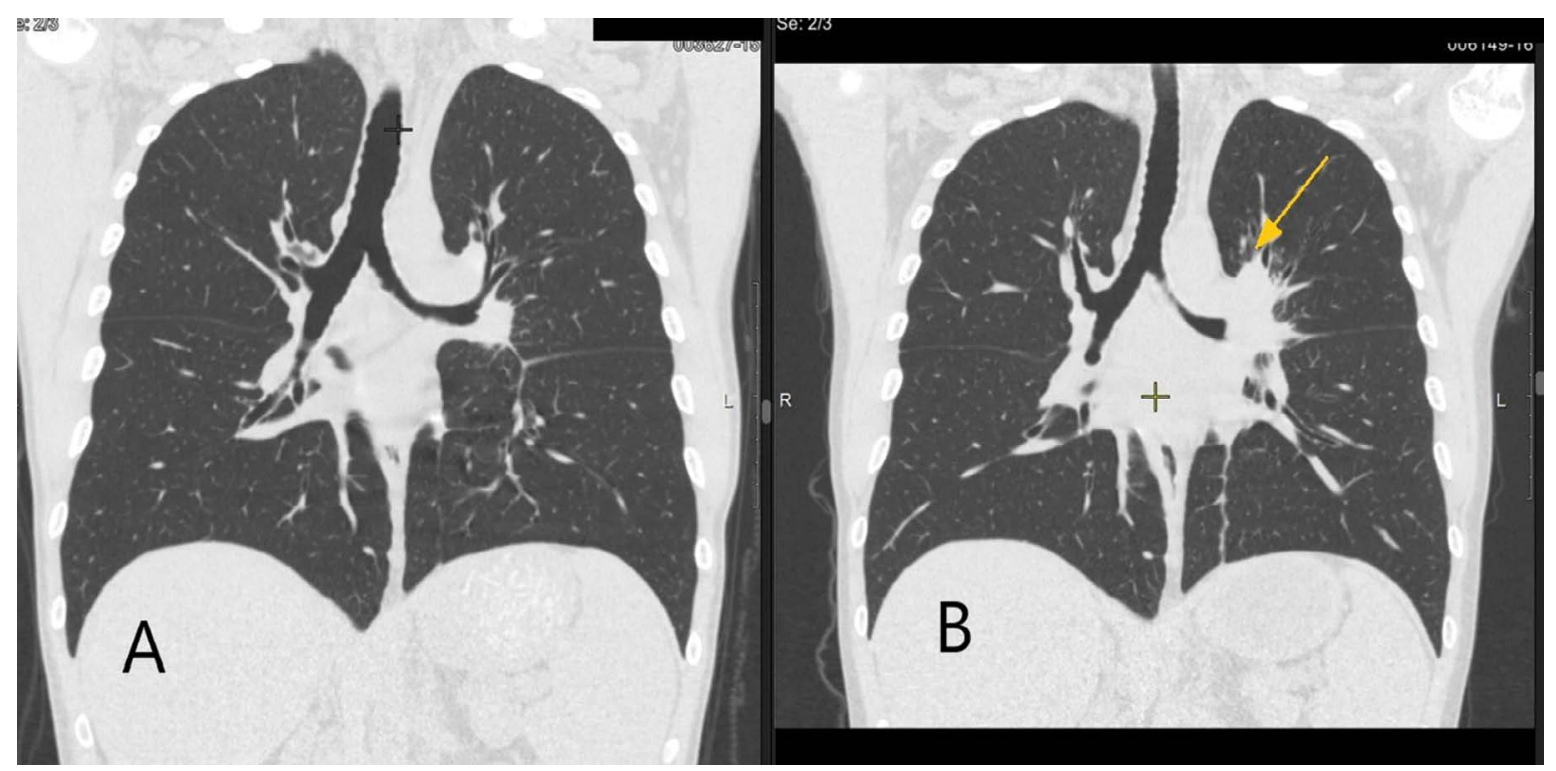

Figure 1. Chest CT scans. A. 06.12.15 (at the beginning of ART and TB preventive treatment); B. 01.06.16 (at onset of symptoms). Radiological worsening with further enlargement of intrathoracic lymph nodes (paratracheal, para-aortic groups and left bronchopulmonary lymph nodes) with perifocal inflammation, compression of bronchi of the left upper lobe, new single foci in the upper lobe of the left lung. 


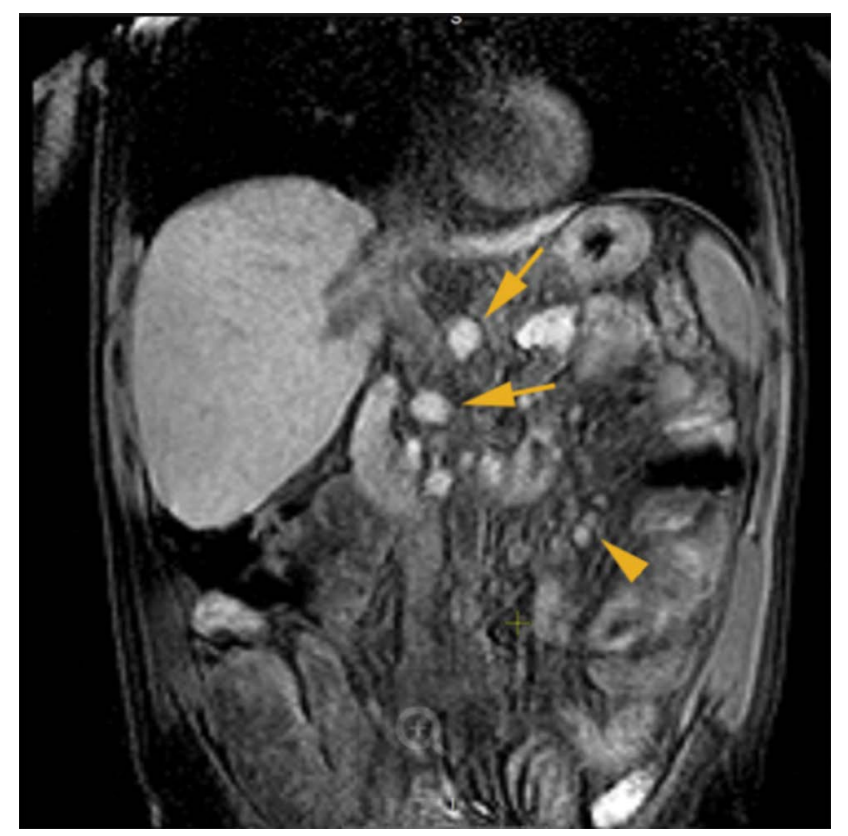

Figure 2. MRI of the abdomen. COR T1+Gd. Enlarged homogenous lymph nodes in the ligament of Treitz. Mesenteric lymph nodes on this scan are not significantly enlarged.

infection, as well as antiretroviral treatment and co-trimaxozole prophylaxis. In January 2017, he underwent liver fibroscan which showed progression of fibrosis - METAVIR score F4, HCV VL was $17000000 \mathrm{IU} / \mathrm{ml}$, his CD4 count remained low $(40-50 \mathrm{cells} / \mathrm{mcl}$, with the maximum of $70 \mathrm{cells} / \mathrm{mcl}$ and suppressed HIV VL). Laboratory tests before treatment revealed anemia ( $\mathrm{Hb} 8.7 \mathrm{~g} / \mathrm{dl})$, and slightly decreased albumin $(3.3 \mathrm{~g} / \mathrm{dl}$ ), other laboratory parameters (thrombocytes, bilirubin, AST, ALT, glomerular filtration rate) were within the normal range. Due to the high risk of further cirrhosis decompensation and development of complications, we decided to initiate treatment of hepatitis $C$.

We started 24 weeks of sofosbuvir/velpatasvir according to EACS guidelines. ${ }^{6}$ Other treatment regimens were corrected in accordance with drugs' interactions: rifabutin was finished (since its usage is not recommended with sofosbuvir/velpatasvir, and according to CDC guidelines for the therapy of disseminated MAC infection, rifabutin is not an obligatory component of the drug regimen $\left.{ }^{7}\right)$. Tenofovir was replaced by abacavir in the ART regimen (HLA-B57 test was negative).

After 4 weeks of therapy VL of HCV decreased to 1500 copies/mcl and at the end of treatment VL was undetectable. At week 12, after treatment cessation, VL remained undetectable; therefore the patient achieved a sustained virologic response, which persists till now (for 30 months). Within the treatment of hepatitis, CD4 increased to 143 cells/mcl by the $25^{\text {th }}$ of May, 2017.

Observation during MAC treatment was based on clinical and radiological findings, sputum and feces AFB fluorescent microscopy. Blood culture for detection of mycobacteria was still unavailable. According to guidelines for MAC-infection treatment, it was over by November 2017: the patient was asymptomatic, previously enlarged lymph nodes reduced (confirmed by CT-scan), there were no acid-fast bacilli at fluorescent microscopy of feces, duration of the treatment was more than 12 months, CD4 cells were $>100$ cells/mcl for more than 6 months.

We observed no side effects of simultaneous ART, MACinfection treatment and treatment of chronic hepatitis $C$ with DAAs.

Nowadays (December 2019), the patient continues observation in the HIV-clinic, antiretroviral treatment and co-trimaxozole prophylaxis. The last results of CD4 and HIV $V L$ (from November 2019) were: 195 cells/mcl (20\%), VL undetectable. He undergoes ultrasound examination 2 times a year ${ }^{8,9}$, the last one (from September 2019) revealed no signs of focal abnormalities in liver and no evidence of portal hypertension worsening. Gastroesophageal endoscopy is in plan.

\section{DISCUSSION}

Disseminated MAC infection is a common problem in patients with advanced immunosuppression. This opportunistic infection can develop as a manifestation of immune reconstitution inflammatory syndrome (IRIS). ${ }^{10}$ Our clinical case presents a classical course of the disease - a subacute development with flu like symptoms, diarrhea, massive involvement of abdominal and thoracic lymph nodes and insignificant involvement of pulmonary tissue.

According to the data, effective treatment of disseminated MAC infection in HIV patients is possible with a combination of a long course of multidrug therapy and an effective ART. This case shows a slower response to ART in the patient with chronic hepatitis $\mathrm{C}$ infection that may compromise successful treatment of such patients.

One of the most prominent benefits of hepatitis $\mathrm{C}$ treatment in HIV patients is a delay in the fibrosis progression. ${ }^{11-13}$ At the same time, some studies show that after hepatitis is cured, patients enhance virologic or/and immunologic response to ART. ${ }^{14}$ All these studies refer to the era of interferon-containing therapy which was restricted in HIV patients. ${ }^{15}$ Interferon-free therapy facilitates treatment of $\mathrm{HIV} / \mathrm{HCV}$ co-infected patients though there are some drug interactions between ART and medications against hepatitis $\mathrm{C}$. The most significant interactions occur when combining direct-acting anti-HCV antivirals with non-nucleoside transcriptase inhibitors (NNRTI: efavirenz, nevirapine, and etravirine) as they can decrease concentrations of DAAs (resulting in a loss of efficacy and potential virological failure) by inducing cytochrome $\mathrm{P} 450$ enzyme system and P-glycoprotein. But still, NNRTI can be combined with sofosbuvir and sofosbuvir/ledipasvir without any dose adjustment. Boosted protease inhibitors (PI) also have significant interactions with anti-HCV antivirals. Nevertheless, sofosbuvir, sofosbuvir/ledipasvir and sofosbuvir/velpatasvir are eligible to be combined 
with PI. Integrase inhibitors have the most favourable interaction profile. Antiretroviral drugs switches may be performed to allow compatibility with DAAs.

Concerning opportunistic infections treatment, the most important drug interactions are connected with rifamycins - rifampicin and rifabutin that are contraindicated in combination with DAAs. With isoniazid and clarithromycin, weak interactions which can require dose adjustment are possible.

\section{CONCLUSIONS}

This clinical case demonstrates that the combined therapy of HIV, chronic hepatitis C, and opportunistic infections becomes possible after a thorough consideration of all drug interactions. Such simultaneous treatment can be the best way to improve outcomes in some clinical situations. All of the above stresses the need to expand the access of HIVpositive patients to the treatment of chronic hepatitis $\mathrm{C}$ with DAAs.

\section{REFERENCES}

1. World Health Organization. Guidelines for the care and treatment of persons diagnosed with chronic hepatitis C virus infection. 2018. Available from: https://www.who.int/hepatitis/publications/hepatitisc-guidelines-2018/en/ [Accessed June 25, 2020].

2. Federal AIDS Centre. HIV-infection. Information Bulletin. Moscow, 2018.

3. Federal Research Institute of Health Organization and Informatics of the Ministry of Health (Russian Federation). TB/HIV in the Russian Federation. Moscow, 2017. Available from: https://mednet.ru/informatizatsiya/tsentr-monitoringa-tuberkuleza [Accessed June 20, 2020]

4. Pokrovskiy VV, Jurin OG, Kravchenko AV, et al. National guidelines on out-patient observation and treatment of HIV-positive patients. Clinical protocol. Epidemiology and infectious diseases. Topical issues. N6, 2015.

5. Griffith DE, Aksamit T, Brown-Elliott BA, et al. An Official ATS/IDSA Statement: Diagnosis, Treatment, and Prevention of Nontuberculous
Mycobacterial Diseases. Am J Respir Crit Care Med 2007; 175(4).

6. EACS guidelines. Version 8.1. October 2016. Available from: https:// www.eacsociety.org/guidelines/guidelines-archive/archive.html [Accessed June 25, 2020].

7. Guidelines for the Prevention and Treatment of Opportunistic Infections in HIV-Infected Adults and Adolescents. Recommendations from the Centers for Disease Control and Prevention, the National Institutes of Health, and the HIV Medicine Association of the Infectious Diseases Society of America. Available from: https://aidsinfo. nih.gov/guidelines [Accessed June 20, 2020].

8. Marrero JA, Kulik LM, Sirlin CB, et al. Diagnosis, staging, and management of hepatocellular carcinoma: 2018 practice guidance by the American Association for the Study of Liver Diseases. Hepatology 2018; 68(2):723-50.

9. Garcia-Tsao G, Abraldes JG, Berzigotti A, et al. Portal hypertensive bleeding in cirrhosis: Risk stratification, diagnosis, and management: 2016 practice guidance by the American Association for the study of liver diseases. Hepatology 2017; 65(1):310-35.

10. Smibert OC, Trubiano JA, Cross GB, et al. Short communication: Mycobacterium avium complex infection and immune reconstitution inflammatory syndrome remain a challenge in the era of effective antiretroviral therapy. AIDS Res Hum Retroviruses 2017; 33(12):1202-4.

11. Benhamou $\mathrm{Y}$, Bochet $\mathrm{M}, \mathrm{Di}$ Martino V, et al. Liver fibrosis progression in human immunodeficiency virus and hepatitis $\mathrm{C}$ virus coinfected patients. The Multivirc Group. Hepatology 1999; 30(4):1054-8.

12. Macias J, Berenguer J, Japon MA, et al. Fast fibrosis progression between repeated liver biopsies in patients coinfected with human immunodeficiency virus/hepatitis C virus. Hepatology 2009; 50(4):1056-63.

13. Konerman MA, Mehta SH, Sutcliffe CG, et al. Fibrosis progression in human immunodeficiency virus/hepatitis $\mathrm{C}$ virus coinfected adults: prospective analysis of 435 liver biopsy pairs. Hepatology 2014; 59(3):767-75.

14. Dazley J, Sison R, Slim J. Long-term consequences of hepatitis C viral clearance on the CD4 (+) T cell lymphocyte course in HIV/HCV coinfected patients. AIDS Research and Treatment Volume 2015, Article ID 687629, 4 pages http://dx.doi.org/10.1155/2015/687629.

15. EACS guidelines. Version 6. October 2011. Available from: https:// www.eacsociety.org/guidelines/guidelines-archive/archive.html [Accessed June 25, 2020]. 


\title{
Одновременное лечение ВИЧ, комплекса распространённых Mycobacterium Avium и инфрекции гепатитом C
}

\author{
Вера Зимина ${ }^{1}$, Светлана Дегтярёва ${ }^{1}$, Елена Белобородова ${ }^{1}$, Юлия Климова ${ }^{1}$, \\ Алексей Кравченко ${ }^{2}$ \\ ${ }^{1}$ Кафедра инфекционных болезней, Российский университет дружбы народов, Москва, Россия \\ ${ }^{2}$ Специилизированная научно-исследовательская лаборатория эпидемиологии и профилактики СПИДа, Центральный научно- \\ исследовательский институт эпидемиологии Федеральной службы по надзору в сфере защить прав потребителей и благополучия человека \\ Роспотребнадзора, Москва, Россия
}

Адрес для корреспонденции: Светлана Дегтярёва, Кафедра инфекционных болезней, Российский университет дружбы народов, ул. Миклухо-Маклая, 6, Москва 117198, Российская Федерация; E-mail: degtyareva_syu@pfur.ru; Тел.: 8-(495)-365-25-33

Дата получения: 2 июля 2020 Дата приемки: 14 июля 2020 Дата публикации: 31 августа 2021

Образец цитирования: Zimina V, Degtyareva S, Beloborodova E, Klimova J, Kravchenko A. Concurrent treatment of HIV, disseminated Mycobacterium avium complex and HCV-infection. Folia Med (Plovdiv) 2021;63(4):586-90. doi: 10.3897/folmed.63.e56124.

\section{Резюме}

Пациенты с ВИЧ-инфекцией, диагностированной на поздней стадии, обычно получают значительную иммуносупрессию и нуждаются в немедленной противовирусной терапии и лечении оппортунистических инфекций. Наличие коинфекции гепатита С делает лечение ещё более сложным из-за возможных побочных эффектов и лекарственного взаимодействия. Лечение инфекции гепатита С в таких клинических ситуациях не только предотвращает развитие фиброза, но также может усиливать вирусологический и / или иммунологический ответ на противовирусные препараты и, следовательно, эффективное лечение оппортунистических инфекций. Тщательный учёт всех существующих заболеваний и лекарственных взаимодействий при комбинированной терапии делает одновременное лечение ВИЧ, хронического гепатита С и оппортунистических инфекций не только возможным, но и лучшим способом улучшить исход в сложной клинической ситуации.

\section{Ключевые слова}

коинфекция, лекарственные взаимодействия, гепатит С, иммуносупрессия, нетуберкулёзные микобактерии 